\title{
Impact of watershed management programme in Chikkanankuppam watershed of Vellore district
}

\author{
M. Chinnadurai ${ }^{1}$, M. Balarubini* and P. Asha Priyanka \\ Department of Agricultural Economics, Centre for Agricultural and Rural Development Studies, \\ Tamil Nadu Agricultural University, Coimbatore (T.N.) India \\ (Email: rubinibala@gmail.com)
}

\begin{abstract}
Watershed development projects have been taken up under different programmes launched by Government of India, State departments and also International Agencies. Watershed management is a concept which recognizes the judicious management of basic resources of soil, water and vegetation, on watershed basis, for achieving particular objective for the well being of the people. Realizing the significance of the watershed development investments on various watershed projects, a detailed study was carried out to evaluate the activities and their impacts. The impact of various activities on different aspects such as water resources, agricultural production, socio-economic aspects and institutional aspects was studied. The overall impact of watershed projects implemented under NABARD Watershed Development Fund (WDF) in Chikkanankuppam has been positive and significant.
\end{abstract}

Key Words : Impact, Bio-physical, Socio-economic, Environmental, Ecological parameters

View Point Article : Chinnadurai, M., Balarubini, M., Priyanka and P. Asha (2019). Impact of watershed management programme in Chikkanankuppam watershed of Vellore district. Internat. J. agric. Sci., 15 (1) : 177-183, DOI:10.15740/HAS/IJAS/15.1/177-183. Copyright@2019: Hind Agri-Horticultural Society.

Article History : Received : 27.09.2018; Revised : 19.12.2018; Accepted : 25.12.2018

\footnotetext{
* Author for correspondence:

${ }^{1}$ Directorate of Centre for Agricultural and Rural Development Studies, Tamil Nadu Agricultural University, Coimbatore (T.N.) India
} 